Journal of Environmental Science and Sustainable Development

Volume 3

Issue 2 December

Article 8

$12-31-2020$

\title{
SUSTAINABLE DEVELOPMENT IN THE ASPECT OF AUDITING IN CONDITION OF TRANSFORMATION OF SOCIAL INSURANCE SYSTEM
}

Muqadamkhon Zokirkhonovna Abdurahmonova

Accounting, Analyze, and Audit Department/ Institute of Economy and Trade of Tajik State University of Commerce, 735700, Republic of Tajikistan, mukaddam81@gmail.com

Follow this and additional works at: https://scholarhub.ui.ac.id/jessd

Part of the Economics Commons

\section{Recommended Citation}

Abdurahmonova, Muqadamkhon Zokirkhonovna (2020). SUSTAINABLE DEVELOPMENT IN THE ASPECT OF AUDITING IN CONDITION OF TRANSFORMATION OF SOCIAL INSURANCE SYSTEM. Journal of Environmental Science and Sustainable Development, 3(2), 355-370.

Available at: https://doi.org/10.7454/jessd.v3i2.1060

This Original Research Article is brought to you for free and open access by the School of Environmental Science at UI Scholars Hub. It has been accepted for inclusion in Journal of Environmental Science and Sustainable Development by an authorized editor of UI Scholars Hub. 


\title{
SUSTAINABLE DEVELOPMENT IN THE ASPECT OF AUDITING IN CONDITION OF TRANSFORMATION OF SOCIAL INSURANCE SYSTEM
}

\author{
Muqadamkhon Zokirkhonovna Abdurahmonova ${ }^{1^{*}}$ \\ ${ }^{1}$ Accounting, Analyze, and Audit Department/ Institute of Economy and Trade of Tajik State \\ University of Commerce, 735700, Republic of Tajikistan
}

*Corresponding author: e-mail: mukaddam81@gmail.com

(Received: 7 September 2020; Accepted: 23 December 2020; Published: 30 December 2020)

\begin{abstract}
In the modern condition of economy transformation, in the result of reformation of social insurance system appeared different problems. In the result of previous research about the transformation of social insurance system we defined some disadvantages of this sphere expressed in candidate dissertation on theme "Features of development and modernisation of social security system in the national economy of Tajikistan". The problems regarding to amount of social insurance influenced to the research in the aspect of auditing. So, just by controlling and revision procedures determines economic based decisions for decreasing problems. Methods. In the process of our research, we used several methods of research work, such as, observation, interviews, comparison analyses and accounting calculations by different important primary materials of SASIP (State Agency of Social Insurance and Pension) of Republic of Tajikistan. Results and discussion. In order to the offered theory, used author's formula (AAR $=\mathrm{Ri} * \mathrm{Rci} * \mathrm{Rnf}$ ) and conceptions of auditing influences to the quality of revision process and by solution defined the real condition of the main indicators of social insurance system. The result of this solution improves the process of audit procedures for correctly making decisions. Conclusion. In the modern of sustainable development of economy each sphere must follow to the time requirements. That is why auditors and accountants of any type of companies, just of social insurance system have to work by national confirmed regulations of the country and in the case of appearing any problem organize discussion clubs for solution them.
\end{abstract}

Keywords: Audit activity; Sustainable development; Social insurance system; SASIP (State Agency of Social Insurance and Pension).

\section{Introduction}

The development of all socio-economic relations of the country is dictated by new conditions for stability continuous economic growth. The proven fact is that one of the factors of economic growth in each country is the development of socio-economic infrastructure (Abdurahmonova, 2017a). In this regard, it is worth noting that the activities of each state in terms of the social security of the population, in particular its vulnerable layers, are very important and necessary. As we know the result of any changes and transformations impact different problems, such as deficit of social 
insurance sums, pensions, and other allowances (Abdurahmonova \& Bukhadirov, 2020). That is why just this problem about auditing of social insurance system became necessary and important in the modern situation of republic. The goal is to soften the transition from the old to the new accounting system for implementation in the social insurance authorities, as a budget organization (Abdurahmonova, 2017b). So, the main gaps of this manuscript are consists of: a) to define the process of introduction of international standards of financial reports and audit in practical activity of social insurance system; b) author's contribution to the sustainable development of the economy of the country in the aspect of auditing of social insurance system; c) to improve the system of accounting of social insurance regarding to international standards; d) to define the modern methods of assessments (auditing) of accounting activity step-by-step; e) to prove the theoretical bases by analytical data (Al-Adeem, 2017).

The accounting process in all areas of activity, in particular in social insurance bodies, is based on a chart of accounts. We can say that in accounting, accounts are a means of communication (language) between accounting professionals. In this regard, the budget chart of accounts is given priority in the social insurance bodies since the noted body is the budget. But it should be noted that at present, almost all budgetary organizations conduct accounting in accordance with generally accepted international standards (Anders, 2020).

But, despite the approved unified chart of accounts of the Republic of Tajikistan for budget organizations by order of the Minister of Finance in 2012, each organization, depending on the specifics of its activities, applies an internal chart of accounts. (Bubnovskaya, 2018) Nowadays in the modern condition of sustainable development there are many problems in industry, agriculture, chemistry, art fields, but the main purpose of these directions is to satisfaction needs of population. It means that we suppose, social-economic sector is the most important part of economy (Anders, 2018).

The main purpose of the audit of the activities of social insurance organizations in terms of the social insurance fund is the establishment and verification of the correctness and timeliness of accounting and reporting in accordance with the legislation of Tajikistan (Bychkova \& Badmaeva, 2018). The necessary components for the audit are considered appropriate in the following areas:

a. adequate and independent verification of the internal control system of social insurance organizations;

b. clarify audit methods that facilitate effective assessment and are suitable specifically for social insurance organizations; and

c. correctly build the process of developing a program of audit procedures, etc. 
Article 39 of the Constitution of the Republic of Tajikistan states that every person is guaranteed social security in old age, in case of illness, disability, disability, loss of sponsor and in other cases provided by law. The founder of peace and national unity - the leader of the nation, President of the Republic of Tajikistan Emomali Rahmon, in one of his speeches noted that "Social protection is one of the priorities of the state's social policy, the main purpose of which is to promote the development of human capital."

The object of the study is the totality of economic relations associated with the implementation of international financial reporting standards in the process of accounting and auditing the financial statements of social insurance bodies in the context of the need for a transition to a digital economy in Tajikistan. The subject of the study is the accounting and elements of the financial statements of social insurance bodies in accordance with IFRS (Bychkova \& Itygilova, 2018).

\section{Methods}

The process of research was accompanied by different economic, statistical, and accounting and auditing methods, such as, by using formulas, analytical tables, formation author's figures, schemes and so on (Vakhrushina \& Prunenko, 2020). In this aspect necessary to note, that correctly calculated every step of the auditor will help to evaluate the essence of the internal control system of social insurance organizations, and also contributes to the logically correct compilation and justification of the result of the audit through an audit report (Jordan \& Clark, 2017).

The theoretical and methodological basis of the study is the fundamental and applied works of domestic and foreign scientists in the theory and practice of accounting and audit of financial statements, the features of the application of IFRS and ISA in social insurance bodies, the method of calculating deductions to the social insurance fund from accrued wages, forms of financial reporting in social insurance bodies according to IFRS in the market conditions of Tajikistan.

So, in the result of our research and analyses in our opinion, a clearly defined plan contributes to an effective assessment of the internal control system of social insurance organizations (Jayeola, Agbatogun, \& Akinrinlola, 2017). But by our opinion compiled program based on a clearly defined audit plan only contributes to the effective conduct of the audit but does not eliminate the risk of an audit (Kudrenko \& Demianchuk, 2019). So, as in all areas of activity, and in audit activity as one of the types of entrepreneurship, there is a risk that can be predicted, forecasted, and calculated (Lantsova, 2019). According to the theoretical foundations, two types of calculation of audit risk are distinguished, in particular, by the method of intuition and the method of calculation. 
Based on our observations, we believe that the calculation method is more adequate, accurate, logical and effective. In this aspect, it is more advisable to use a transformed factor model of audit values:

$$
\mathrm{AAR}=\mathrm{Ri} * \mathrm{Rci} * \mathrm{Rnf}, \text { where: }
$$

AAR - acceptable audit risk;

$\mathrm{Ri}$ - internal risk of the enterprise;

Rci - risk control tools;

Rnf - the risk of not being detected.

But when determining the risk of non-detection, some difficulties arose with accuracy, in connection with this we turned to statistical data, according to which the named risk is proposed to be set at $10 \%$. So, it should be remembered that the first two types of risk directly affect the last type of risk and have a proportional correlation.

The first calculation step: $\mathrm{AAR}=0.78 * 0.82 * 0.10=0.06396$;

So, we can verify the correctness of the compiled factor model by the feedback model.

The second step of the calculation (validation):

$$
\mathrm{Rnf}=0.064 \% /(0.78 * 0.82) * 100=10 \%
$$

The third step of the calculation (validation check):

$$
\mathrm{Rci}=0.064 /(0.10 * 0.78) * 100=82 \% \text {; }
$$

The fourth step of the calculation (control checking):

$$
\mathrm{Ri}=0,064 /(0,10 * 0,82) * 100=78 \%
$$

In this regard, it should be noted that according to the National Development Strategy of the Republic of Tajikistan for the period up to 2030. The main priorities of the country's development at present are education, health care, employment, financial inequality of the population, the fight against corruption, food security and nutrition, effective management, social protection of the population, prevention (prevention) of potential conflicts, energy security, ecology, and management of demographic processes (Lehmann, 2020). The main object of accounting in social insurance organizations is the social insurance fund, in accordance with this fact, when evaluating the internal control system, the bias towards the specified object (Figure 1). 


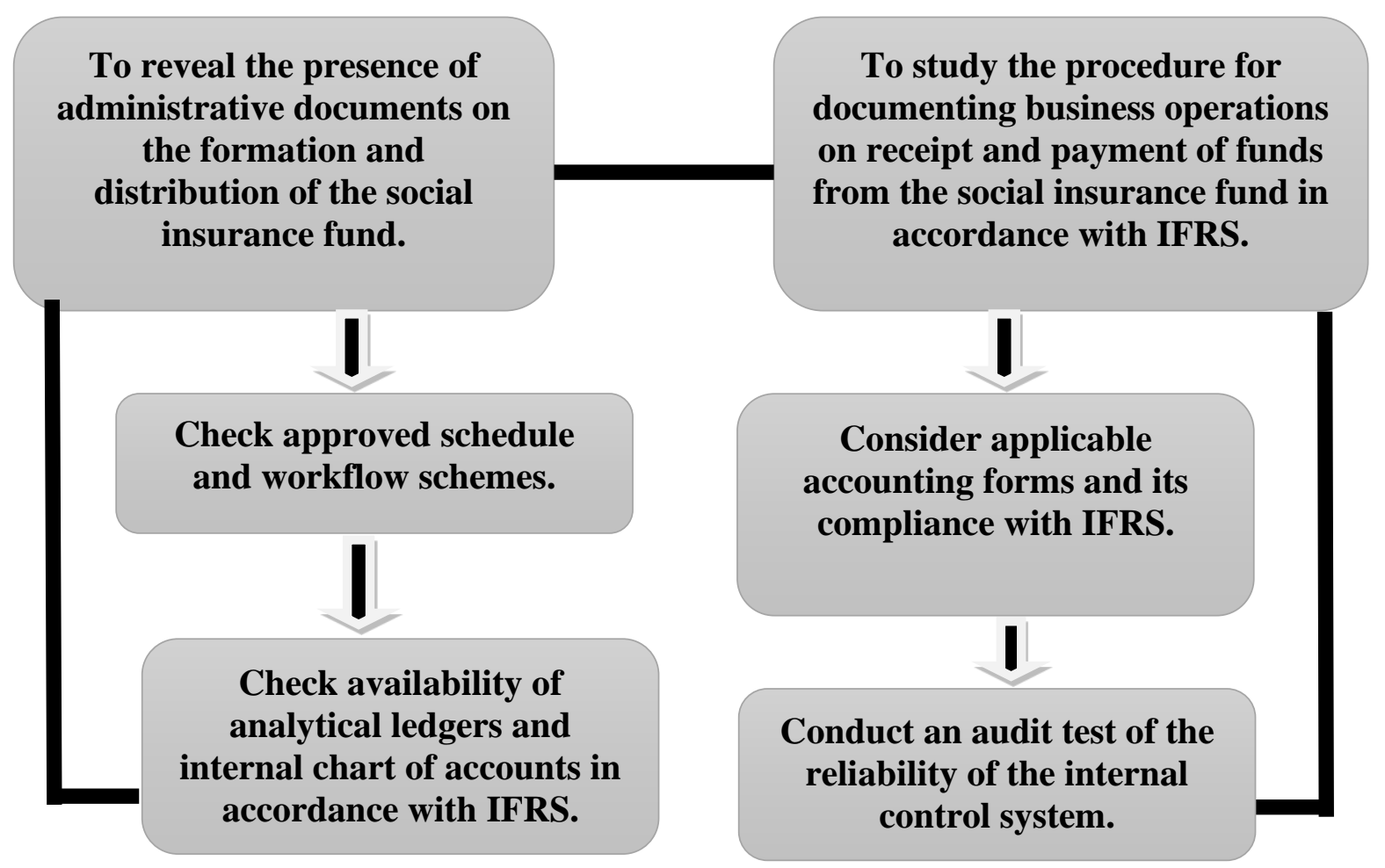

Figure 1. Methodology of step-by-step assessment of the internal control system of social insurance organizations (compiled by the author)

Source: Loskutova (2020)

Regarding to the IFRS and accounting of social insurance system as one form of budget organization consist of some features of auditing consider of checking or revision (Loskutova, 2020). Because by our opinion, it is more efficiency and accurately step-by-step method of auditing of budget organizations, that is social insurance system (Millman, 2019). It is well known that the direct means of achieving the goal is correctly defined tasks. So, the audit in terms of the social insurance fund consists of the following elements (Mishra, 2020):

a. the correct definition of the salary fund in order to deduct insurance premiums;

b. compliance with the rules of accounting in social insurance organizations in accordance with IFRS;

c. monitor the correct determination of amounts not subject to social insurance taxation;

d. calculation of the tax base strictly according to tax regulatory legal acts;

e. the correct application of tax rates;

f. timeliness and completeness of the transfer of contributions, making the corresponding payments;

g. the correctness and validity of the use of benefits; 
h. comparing the records of synthetic and analytical accounting on the account "Social Insurance Fund" with the data of the general ledger and the balance sheet of the social insurance organizations; and

i. the correctness and timeliness of the compilation of financial reporting forms in social insurance organizations, in particular regarding the social insurance fund.

\section{Results and Discussion}

In the result of research work, offered basic and fruitful stages of audit planning in order to the features of insurance system. In according to this stage defined the main procedures of auditing regarding to international standards (Omolaye \& Jacob, 2017). The results of these research can be uses in the practical activity of internal audit department of social insurance agency. As we know insurance is an economic category that protects the interests of individuals and legal entities from certain unforeseen consequences (insured events) due to the payments they form (membership fees). The essence of insurance in its functions is clearly defined (Plaskova, 2020). With the development of market relations, more attention will be paid to the field of insurance and insurance analysis. Insurance comes from the Latin word fear, which means panic. State social insurance is a popular type of personal insurance and occupies a prominent place in the economy, especially in the social sphere (Rastegaeva \& Rahmatullin, 2016).

Actuality of this problem expresses by the political orientation to the activity of social insurance agency. Just by total forces of scientists, practical specialists, and government we can get profitable results. Therefore, in the Message of this year, the Founder of Peace and National Unity - the Leader of the Nation, the President of the Republic of Tajikistan Emomali Rahmon paid special attention to the practical implementation of strategic goals, which is a key factor in the development of a country worthy of life and international reputation. The issue of social insurance and the pension system, raising the level of social services for pensioners and sustainable provision of the financial system of social insurance are also important topics in the Message.

In this regard, it was noted that "the budget of social insurance and pensions, which in 2013 amounted to 1 billion 683 million somoni, in 2020 is projected at 3.2 billion somoni, which is almost twice as much as in 2013 year. Currently, there are 700,000 pensioners in the country, including 148,000 disabled people, 5,277 orphans and 74,000 orphans who are under state care. This year, more than 36 million somoni was allocated from the state budget to institutions for the elderly and disabled, which amounts to 22,600 somoni per person". At the same time, to further improve the social conditions of pensioners in the country, the Supreme Leader of the nation 
instructed to increase the minimum and maximum old-age pensions and basic pensions, as well as pensions by 15\% from September 1, 2020 year. Social insurance is provided in part by organizations and individual entrepreneurs - employers, who act as insurers who pay insurance premiums.

One of the most important areas of accounting for each enterprise, both in Tajikistan and abroad, is the calculation of salaries and contributions from the enterprise. Accounting for social insurance is one of the most time-consuming and responsible areas of work for an accountant. In fact, it occupies one of the central positions in the entire enterprise accounting system.

Just as we know the heart of every organization, so social insurance bodies are accounting. A feature of the chosen problem lies in the study of accounting and financial reporting issues in the social insurance authorities (Reuters, 2018). Some changes in the field of accounting, i.e., transition to IFRS, ISA, as well as adjustments in legislative acts in the field of social insurance. According to our observations and research results, in urgent form there was a need for harmonization of accounting and reporting in social insurance bodies (Reuters, 2017).

According to modern literature, the state social insurance system was formed at the end of the XVIII century. The country of origin of this type of insurance is Germany, which on June 15, 1883, the Reichstag adopted a law on compulsory state health insurance. On June 22, 1884, the accident insurance law entered into force. On July 22, 1889, compulsory disability and old-age insurance was introduced. The Law of the Republic of Tajikistan "On State Social Insurance" was adopted on December 13, 1997 at the sixth session of the Majlisi Oli of the Republic of Tajikistan. It was necessary to adopt this law in 1991, after the independence of the Republic of Tajikistan, and create a legislative framework that would meet the changing economic conditions of the country. Prior to the adoption of this law, the activities of social insurance institutions were regulated by laws adopted during the existence of the USSR. Therefore, the adoption of the Law on State Social Insurance is an important step towards ensuring the sustainability of the sovereignty of Tajikistan.

In order to ensure the social interests of citizens and the interests of the state, a law is provided on compulsory state insurance of life, health, and property of certain groups of public servants (employees). Article 1056 of the Civil Codex of the Republic of Tajikistan provides for compulsory state insurance at the expense of funds allocated for these purposes from the state budget in case of loss of wages, income, illness, disability, pregnancy, old age, or loss of life, unemployment, death, and other cases prescribed by law.

Rules for conducting inspections of compliance with legislation in the field of social insurance and pension provision in the activities of business entities on the basis of Part 2 of Article 8 of the 
Law of the Republic of Tajikistan "On Inspecting Business Entities” and paragraph 9 of May 25, 2017, No. 265 “On the Rules for Conducting Inspections of Business Entities”, the procedure for conducting inspections of business entities for compliance with legislation in the field of social insurance and pension benefits in organizations and institutions, regardless of ownership and type of activity, as well as other entities, was approved, developed and developed. The budget for social insurance and pensions is determined by officials in the field of social insurance and pensions (Radin, 2018).

Inspection of inspecting entities is carried out on the basis of the Law of the Republic of Tajikistan "On Inspection of Business Entities", Decree of the Government of the Republic of Tajikistan dated May 25, 2017, 5265 "On Typical Rules for Inspecting Entities of Entrepreneurship", these Regulations and other relevant regulatory acts of the Republic of Tajikistan. Violation of the Rules of verification in the field of social insurance and pensions during the inspection of business entities and entities financed from the budget of social insurance and pensions by officials in the field of social insurance and pensions of economic entities", Decree of the Government of the Republic of Tajikistan dated May 25, 2017 No. 265“On typical rules for conducting inspections of business entities" and the established procedure.

Checking the activities of business entities and entities financed from the budget of social insurance and pensions by officials to ensure compliance with the legislation of the Republic of Tajikistan in the field of social insurance and pension provision, the targeted use of budget funds for social insurance and pension provision Subjects financed from the budget of social insurance and pensions are carried out in the process of carrying out their activities. There are several main purposes of the audit (Figure 2).

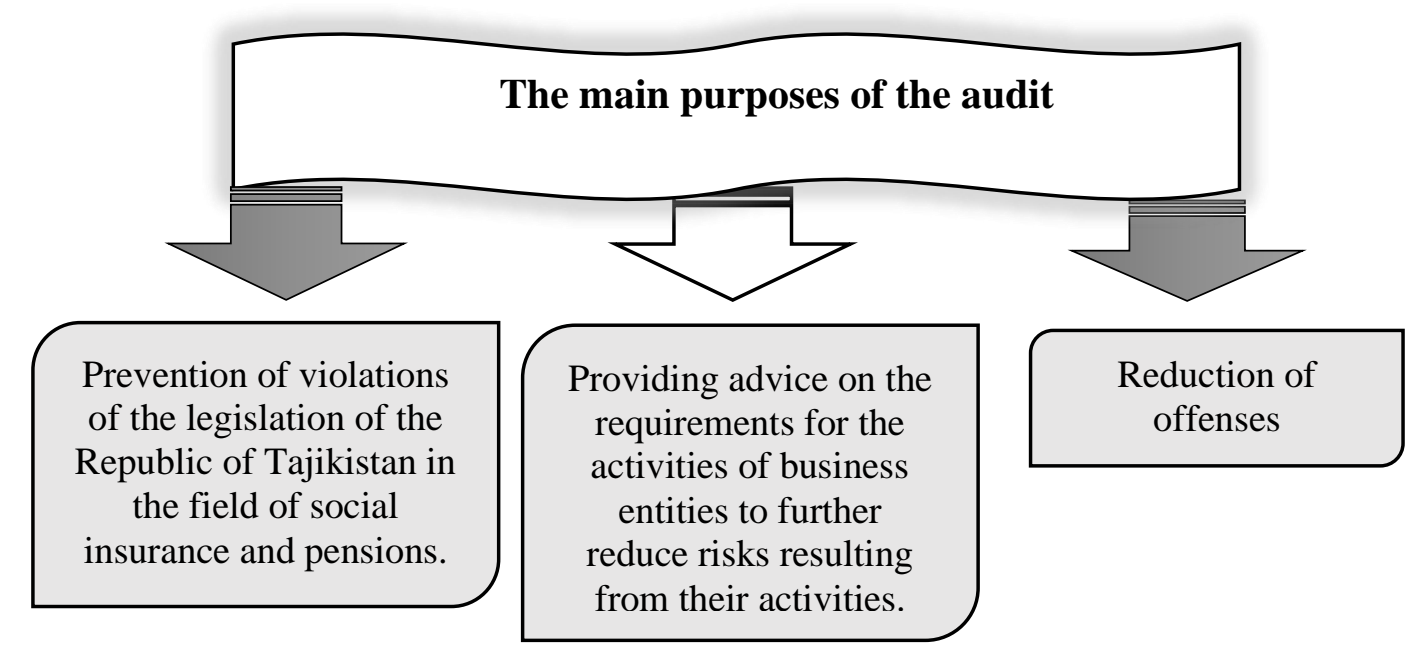

Figure 2. The purposes of the audit regarding to international standards

Source: Abdurahmonova \& Bukhadirov (2020) 
Regarding to this figure scientists in the sphere of social insurance agency and their auditing department can use this refreshed purpose of audit in order to international standards (Radin, 2018). Checks of compliance with the legislation of the Republic of Tajikistan in the field of social insurance and pension provision only on the basis of the relevant Order of the inspection body, which has the right to review and impose administrative penalties in the field of state social insurance and pensions is the director of the Agency, the heads of departments of the Agency in all regions and the head of the Agency in Dushanbe. The powers of the officials of the Social Insurance and Pension Agency responsible for conducting inspections are determined by the Law of the Republic of Tajikistan "On Inspection of Entrepreneurship Entities" and other regulatory legal acts in the field of social insurance and pension provision of the Republic of Tajikistan. Agency officials responsible for the audit, when conducting an audit of the activities of business entities, are required to: (Table 1)

Table 1. Duties and rights of agency officials

\begin{tabular}{|c|c|c|}
\hline No. & Agency Responsibilities & Individual rights \\
\hline 2 & $\begin{array}{l}\text { Make entries in the registry of inspections of business } \\
\text { entities } \\
\text { Explain to the business entity the subject and essence } \\
\text { of the revealed violations and deficiencies in the field } \\
\text { of social insurance and pensions and take measures to } \\
\text { eliminate the } \\
\text { To substantiate the validity of their actions in } \\
\text { complaints of business entities in the manner } \\
\text { established by the legislation of the Republic of } \\
\text { Tajikistan }\end{array}$ & $\begin{array}{l}\text { Request the necessary information from the } \\
\text { business entity for the implementation of its } \\
\text { powers and responsibilities (if necessary, } \\
\text { directly familiarize yourself with the source } \\
\text { data), as well as, if necessary, receive prices } \\
\text { and copies of documents. } \\
\text { Draw up acts and protocols of violations in } \\
\text { accordance with applicable law. }\end{array}$ \\
\hline
\end{tabular}

Source: Processing of the author according to the Code of Ethics for Officials of Inspection Bodies (Decree of the Government of the Republic of Tajikistan of October 7, 2016 No. 421)

Agency officials responsible for conducting the audit should strictly adhere to the principles, norms and rules of the Code of Ethics for Inspection Officers approved by the Government of the Republic of Tajikistan on October 7, 2016 No. 421. The inspection procedure is established by the Law of the Republic of Tajikistan "On Inspection of Entrepreneurship Entities", the Model Rules for Inspections of Entrepreneurship Entities and these Rules. 
Agency inspections are carried out in accordance with the approved annual inspection plan (Smirnov, 2020). The annual inspection plan for next year will be developed and approved by the Coordinating Council of the inspection bodies and after its approval will be posted on its official website, as well as in the media to identify business entities (Soboleva \& Zuga, 2020).

The annual plan of scheduled inspections of the Agency is developed on the basis of periodic inspections, which are established for each risk group considering the risk level of each business entity. Criteria for assessing the degree of risk are determined in accordance with the Rules for determining criteria for assessing the degree of risk of a business entity approved by the Government of the Republic of Tajikistan dated April 28, 2017, No. 213. The annual inspection plan of the Agency is changed every six months depending on changes in the level of risk, and these changes are agreed with the Coordinating Council of inspection bodies and approved by the first head of the Agency. At the same time, the changes will be posted on its official website, as well as through the media to identify business entities. Monitoring the implementation of the inspection plan is carried out by the first head of the inspection body (Thomson, 2017).

Agency officials responsible for conducting inspections should visit newly created business entities, with the exception of business entities with a high level of risk, during the first two years of their work only to provide methodological assistance and consultation on inspections. The complaint of an economic entity based on the results of the audit should contain the essence of the complaint and a request for an additional audit. Also, the order of the Agency's management to conduct additional checks based on the statement of the business entity must be adopted within 3 business days from the date of receipt of the application. An order to verify a business entity is carried out by the head of the inspection body, who, in accordance with paragraph 2 of Article 1211 of the Code of Administrative Offenses of the Russian Federation, is entitled to review and impose administrative penalties in the field of state social insurance and pensions. in the regions and the head of the Agency's department in Dushanbe.

The audit of a business entity begins with the submission of the official identity of the audit officer to the mandatory familiarization of the business entity with the signed Order on conducting the audit and making notes about the audit in the audit log (Abdurahmonova \& Bukhadirov, 2020). An audit of a business entity is also carried out for the period specified in the Order and notification of the audit, and strictly in accordance with the list of control questions used in the subject of the planned audit. It is forbidden to go beyond the control questions during the scheduled inspection.

Given the specific tasks of conducting an audit of accounting in SASIP, an important component is the existence of a plan and audit program. The fundamental initial step in conducting an audit is 
planning. Planning is the process of preparing an audit plan, including forecast data on the volume, period, schedule of the audit and on the basis of which the audit program is developed. Basically, to conduct an audit, specialists first carry out preliminary planning, draw up an audit plan, and then develop an audit program. This sequence is a typical audit chain structure. But in view of some of the features of accounting in SASIP, considering reforms in the field of accounting in accordance with IFRS, we propose to begin an audit with a predictive and strategic assessment of the amount of work ahead (Figure 3).

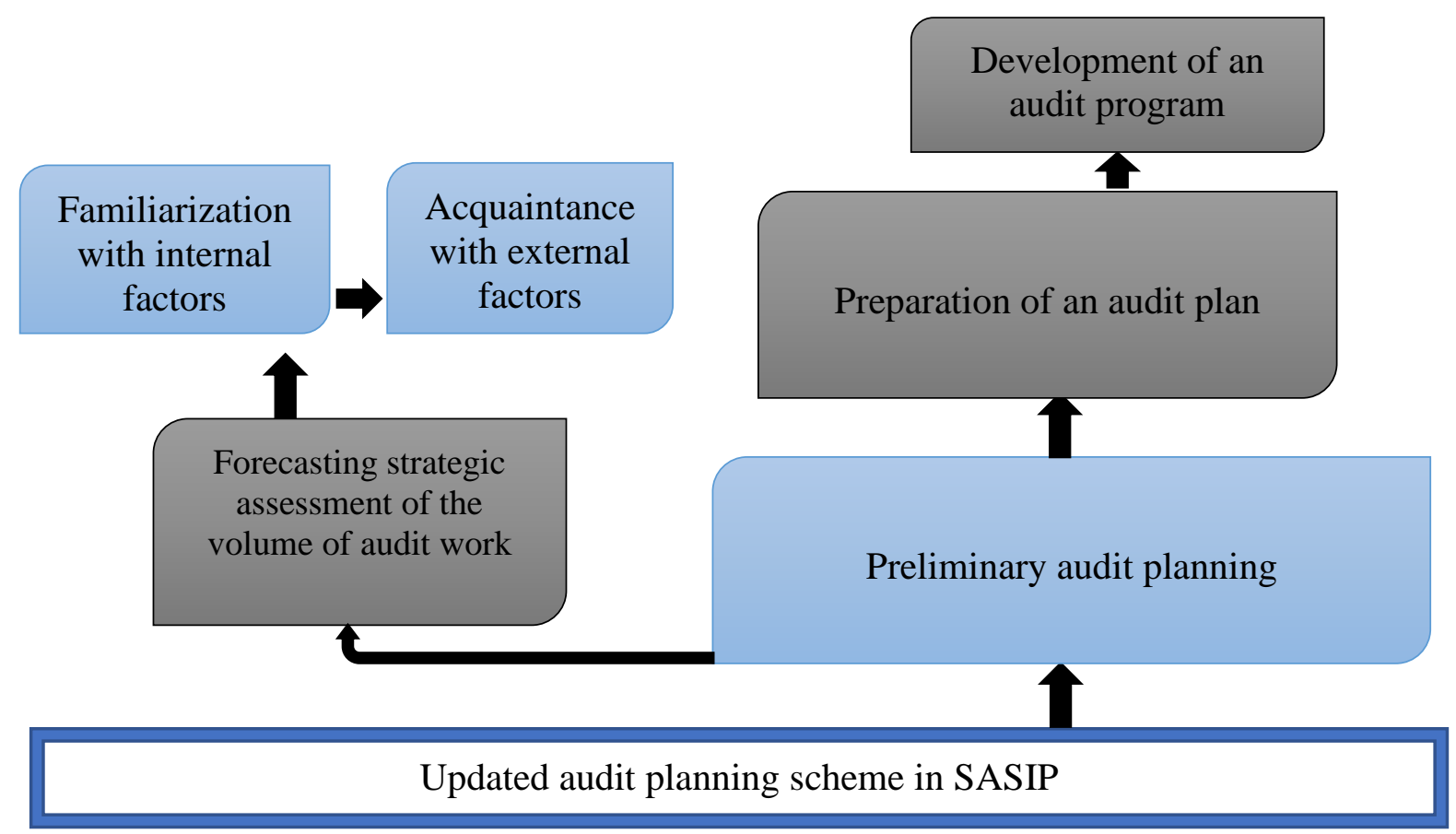

Figure 3. Updated SASIP audit planning scheme in the context of accounting reform

Since, in case of uncertainty of a certain picture, the plan and the audit program will have significant differences from the actual work. The analytical information of the audit plan is more accurately and fully reflected in the audit program. The audit program describes comprehensive ways to control and verify accounting in accordance with international standards. Among the above priorities, the system of social protection of the population takes eighth place. A practical confirmation of the degree of priority of social protection issues is the contribution of budgets of various levels to the solution of social security issues (Waymire, Webb, \& Timothy, 2019).

So, in order to implement the Strategy for improving the public sector accounting system of the Republic of Tajikistan for the periods 2011-2018, also considering the adoption of the International Standard for Financial Reporting, it was approved that the cost estimate of the Social Insurance and Pensions Agency is partially covered by the state budget. So, after brought calculations we should 
conduct auditing of expenses of SASIP of Republic of Tajikistan by conditional materials of this Agency (Table 1). All known that it is impossible to consider all sides of auditing of SASIP in the framework of one research work. That is why we brought the comparison analyze of several allowances below in the Table 2 .

Table 2 Comparison analyze of planned expenses for half month of 2019 year regarding for the same period of 2018 year.

(in thousand somoni)

\begin{tabular}{|c|c|c|c|c|c|c|c|c|c|}
\hline \multirow{2}{*}{$\begin{array}{c}\text { Kinds of } \\
\text { allowances }\end{array}$} & \multicolumn{3}{|c|}{ Budget } & \multicolumn{3}{|c|}{ Non-budget } & \multicolumn{3}{|c|}{ Total } \\
\hline & 2018 & 2019 & $\begin{array}{l}\text { Deflec- } \\
\text { tion }\end{array}$ & 2018 & 2019 & $\begin{array}{l}\text { Deflec- } \\
\text { tion }\end{array}$ & 2018 & 2019 & $\begin{array}{l}\text { Deflec- } \\
\text { tion }\end{array}$ \\
\hline $\begin{array}{l}\text { Temporary } \\
\text { disability }\end{array}$ & 111,8 & 81,4 & 30,4 & 120,9 & 111,8 & 9,1 & 232,8 & 191,8 & 41,0 \\
\hline $\begin{array}{l}\text { Pregnancy } \\
\text { and birth }\end{array}$ & 245,2 & 248,2 & -3 & 120,1 & 245,2 & $-125,1$ & 365,4 & 392,2 & $-26,8$ \\
\hline $\begin{array}{c}\text { On care for } \\
\text { child till } 1,5 \\
\text { age }\end{array}$ & 35,5 & 40,7 & $-5,2$ & 7,1 & 35,5 & $-28,4$ & 42,6 & 49,0 & $-6,4$ \\
\hline $\begin{array}{c}\text { Lump } \\
\text { allowance }\end{array}$ & 5,7 & 5,1 & 0,6 & 0,9 & 5,7 & $-4,8$ & 6,6 & 5,2 & 1,4 \\
\hline $\begin{array}{c}\text { Resort } \\
\text { treatment } 1,4 \%\end{array}$ & 46,8 & 52,2 & $-5,4$ & 61,0 & 46,8 & 14,2 & 107,9 & 132,8 & $-24,9$ \\
\hline Total & 445,00 & 427,6 & 18,0 & 310,0 & 445,0 & -135 & 755,3 & 771,0 & $-15,7$ \\
\hline
\end{tabular}

Source: Conditional accounting materials of SASIP (author's calculations)

In the result of brought calculations of table 1, it can be seen that for the first 6 months of 2019 , social benefits, considered from the Agency's budget in organizations and institutions of the country as expenses, amounted to 771.1 thousand somoni, which is $2 \%$ of the calculated social tax (15.8/ $771.1 \mathrm{x}$ 100). The analysis showed that for the first 6 months of 2019, the Agency's budget expenditures increased by 755.3 thousand somoni or 15.8 thousand somoni compared to the same period in 2018 year.

The peculiarity of the audit of reports is that the annual financial statements are as of January 1 after the reporting period, and periodic reports, including quarterly as of April 1, semi-annual as of DOI: $\underline{\text { https://doi.org/10.7454/jessd.v3i2.1060 }}$ 
July 1, nine-month as of October 1, as in print in electronic form. The report on the execution of the estimates of income and expenses is submitted no later than the 10th day of each month.

It should also be noted that the financial statements should be provided by the growth method from the beginning of the year in national currency with the allocation of budget funds and approved terms. The main distributors of the republican budget funds provide consolidated financial statements to a higher authority of the central treasury.

Based on the factor calculation performed, the auditor can practically realistically evaluate the SASIP accounting and reporting system through audit procedures. Conducting audit procedures involves the analytical verification of entries in the accounts of debit and credit turnover and their balances. It is a list of all such procedures that should be reflected in the audit program separately. As noted above, this model considers factors affecting the determination of the amount of acceptable audit risk. Based on the practical data of the SASIP activity, we attempted to calculate the audit risk. Typically, the audit risk should be within the established framework (from 0 to 1 ). Presumably, the risk within SASIP is $78 \%$, and the risk of control is $82 \%$, since the control at this agency is at a fairly good level (the agency has an internal control system, in particular, an internal auditor). So, offered results of research influence to the improvement of auditing in the sphere of social insurance agency (pension fund).

\section{Conclusion}

We would like to note, that on the bases of research in auditing direction by international standards gave us to receive several accurate data about the features of accounts in non-budget organizations, forms of accounting documentations and some offered methods of auditing just in social insurance system. But international standards for our country it is something new and as everyone knows introduction innovation into really practice it is always long-time and difficult. That is why we can prove, that nowadays our accounting specialists are working just by international standards, but in the process of practical activity usually appears some problems, which have to solve, and this solution reaches by discussions of scientists, practical specialists and so on.

As a result of a research analysis of the process of audit of accounting and the provision of financial statements, we believe that, depending on the source of financing, features of accounting and reporting have been identified. In this regard, the conducted research work contributes to the solution of some of the problems associated with the transition to IFRS; it is impossible to consider all the existing features of accounting in social insurance bodies within one work. For reaching sustainable development theoretical and practical specialists must combine their endowments and 
knowledge in this direction. Just by this way by new steps of auditing our specialists shall influence to the improvement of auditing of social insurance system.

\section{References}

Abdurahmonova, M. Z. (2017a). On the question of the study of the conceptual-categorical apparatus of social support of the population in a transformational economy. Bulletin of the Tajik National University, 2(1). 123-127 (in Russian).

http://ec.vestnik-tnu.com/index.php/ru/vestnik-tnu-2017-2-1.html

Abdurahmonova, M. Z. (2017b). Some trends in solving the problems of social security. Bulletin of St. Petersburg State Agrarian University, 1(46) (in Russian). https://spbgau.ru/files/nid/5583/izvestiya_146.pdf

Abdurahmonova, M. Z. \& Buhadirov. H. I. (2020). The features of social protection of vulnerable segments of population in the stability development economy condition of Tajikistan (in english). American Journal of Economics and Business Management, 3(1), 266-272. https://www.grnjournals.us/index.php/AJEBM/

Al-Adeem, K. R. (2017). A Need for Theorizing Corporation: An Accounting. International Journal of Accounting Research, 5(2), 166.

https://www.longdom.org/open-access/a-need-for-theorizing-corporation-an-accountingperspective-2472-114X-1000166.pdf

Anders, S. B. (July 6, 2018). Nonprofit accounting resources. The CPA Journal: The Voice of The Profession. https://www.cpajournal.com/2018/07/06/best-search-engines-for-accountants/

Anders, S. B. (May 22, 2020). Nonprofit accounting resources. The CPA Journal: The Voice of The Profession. https://www.cpajournal.com/2020/05/22/nonprofit-accounting-resources/

Bogachenko, V. M., Kirillova, N. A. (2018). Accounting. D: Phoenix (in Russian). https://nsportal.ru/npo-spo/ekonomika-i-upravlenie/library/2018/05/15/uchebnik-v-mbokachenko-n-a-kirillova

Bubnovskaya, T. V. (2018). Problems of audit of the formation of financial results. State University of Economics and Service (in Russian). https://cyberleninka.ru/article/n/problemyaudita-formirovaniya-finansovogo-rezultata

Bychkova, S. M., Badmaeva, D. T. (2018). Accounting and analysis: Textbook Standard of the third generation (in Russian). SPb: Peter. https://www.labirint.ru/books/608017/ 
Bychkova, S. M. (2018). Accounting and analysis: Textbook (in Russian). Peter. https://library.bntu.by/bychkova-s-m-buhgalterskiy-uchet-i-analiz-dlya-bakalavrov-ispecialistov

Bychkova, S. M., \& Itygilova E. Y. (2018). The procedure for the formation of the final audit documents IFRS and ISA in a credit institution. https://docplayer.ru/56879358-Bychkova-s-mitygilova-e-yu-mezhdunarodnye-standarty-audita-ucheb-posobie-pod-red-s-m-bychkovoy-mtk-velbi-izd-vo-prospekt-s.html

Jordan, C. E., \& Clark, S. J. (September 25, 2017). The prevalence of CPAs in the accounting academy. The CPA Journal: The Voice of The Profession.

https://www.cpajournal.com/2017/09/25/prevalence-cpas-accounting-academy/

Jayeola, O., Agbatogun, T. O., \& Akinrinlola, T. O. (2017). Audit Quality and Earnings Management among Nigerian Listed Deposit Money Banks. International Journal of Accounting Research, 5(2), 1-5.

https://www.longdom.org/open-access/audit-quality-and-earnings-management-amongnigerian-listed-depositmoney-banks-2472-114X-1000159.pdf

Kudrenko, N. V., \& Demianchuk S. Y. (2019). Information systems and technologies in the audit. Formation of market relations in Ukraine \#5(216). https://cyberleninka.ru/article/n/informationsystems-and-technologies-in-the-audit/viewer

Lantsova, A. D. (2019). Organization of the system of internal control of the costs of the organization's labor remuneration as a necessary component of effective management. Young Scientist, 4(2). https://moluch.ru/archive/63/10181/

Lehmann, D. (2020). Next-generation internal audit governance. The CPA Journal: The Voice of The Profession.

https://www.cpajournal.com/2020/06/01/next-generation-internal-audit-governance/

Loskutova, M. A. (2020). The Development of the Insurance Market in the Context of Digitalization and Consolidation.Accounting Analysis Auditing, 7(5), 44-55 (in Russian). https://doi.org/10.26794/2408-9303-2020-7-5-44-55

Millman, C. M. (April 30, 2019). Avoiding litigation when auditing government contractors. The CPA Journal: The Voice of The Profession. https://www.cpajournal.com/2019/04/30/avoidinglitigation-when-auditing-government-contractors/

Mishra, A. K. (2020). Conceptual Framework of Natural Accounting. International Journal of Accounting Research, 8.

https://www.longdom.org/open-access/conceptual-framework-of-natural-accounting.pdf 
Omolaye, K. E., \& Jacob R. B. (2017). The role of internal auditing in enhancing good corporate governance practice in an organization. International Journal of Accounting Research, 6(1), 174. https://www.longdom.org/open-access/the-role-of-internal-auditing-in-enhancing-goodcorporate-governancepractice-in-an-organization-2472-114X-1000174.pdf

Plaskova, N. S. (2020). Financial Controlling as a Function of Managing an Organization's Strategy. Accounting Analysis Auditing, 7(5), 24-32 (in Russian).

https://doi.org/10.26794/2408-9303-2020-7-5-24-32

Rastegaeva, F. S., \& Rahmatullin A. M. (2016). Modern approaches for the projects in the internal audit. International Scientific Research Journal, 1(43), 72-75.

https://doi.org/10.18454/IRJ.2016.43.060

Reuters, T. (October 12, 2017). Audit practice alert provides guidance for revenue standard. The CPA Journal: The Voice of The Profession. https://www.cpajournal.com/2017/10/12/auditpractice-alert-provides-guidance-revenue-standard/

Reuters, T. (December 10, 2018). Tax and accounting update. The CPA Journal: The Voice of The Profession. December. https://www.cpajournal.com/2018/12/10/tax-accounting-update-25/

Radin, A. J. (August 24, 2018). Are audit committees worth the cost?. The CPA Journal: The Voice of The Profession. https://www.cpajournal.com/2018/08/24/are-audit-committees-worth-thecost/

Smirnov, V. V. (2020). Integral Strategic Performance - Optimization of a Company's Activity with the Requirements of Interested Parties. Accounting Analysis Auditing, 7(5), 15-23 (in Russian). https://doi.org/10.26794/2408-9303-2020-7-5-15-23

Soboleva, G. V., \& Zuga, E. I. (2020). Gender Policy of Auditing Companies in Russia: Current Situation and Prospects. Accounting Analysis Auditing, 7(5), 56-68 (in Russian). https://doi.org/10.26794/2408-9303-2020-7-5-56-68

Thomson, J. (October 6, 2017). Is the accounting profession committed to closing the skills Gap. The CPA Journal: The Voice of The Profession.

https://www.cpajournal.com/2017/10/06/accounting-profession-committed-closing-skills-gap/

Vakhrushina, M. A., \& Prunenko M. A. (2020). The Relationship Between Procedures of Management Accounting and Internal Control. Accounting Analysis Auditing, 7(5), 80-90 (in Russian). https://doi.org/10.26794/2408-9303-2020-7-5-80-90

Waymire, T. R., Webb, T. Z., \& West, T. D. (May 8, 2019). To Audit or Not to Audit. The CPA Journal: The Voice of The Profession. May. https://www.cpajournal.com/2019/05/08/to-auditor-not-to-audit/ 